\title{
Departing 'Secularism': boundary appropriation and extension of the Syrian state in the religious domain
}

\section{Abstract}

Despite the official secularity of the Syrian state, religion has always been a viable instrument used by the $\mathrm{Ba}$ athist regime to consolidate its authority and legitimacy. Taking different historical trajectories ranging from confrontation to co-optation, the boundaries between state and religion have shifted to conflation in the post-2011 uprising. The official political rhetoric has become explicitly religious and anti-secular, ending an era of official secularity since the 1970s. This newly employed religious rhetoric is evident in the presidential discourse, which is heavily and explicitly infused with religious language. Analysis of Bashar al-Assad's speech to high-ranking ulama in 2011 and his other public statements on the website of the Ministry of Awqaf provides evidence not only of how such religious language marks the move from secularity, which was used to strategically co-opt religious institutions up to 2010, but also how the deployment of religion has become a source of security, legitimacy and survival for the Ba' athist regime since 2011.

\section{Keywords}

Presidential speech, content analysis, Ba' athism, regime legitimacy and survival 


\section{Introduction}

Since the formation of the modern Syrian state, the Ba athist regime has consistently tried to maintain [/and gain hegemony over its heterogeneous subjects. The regime was able to institutionalize its authoritarian rule by establishing social contracts that lasted until 2011. However, the current conflict has produced a unique confrontation and crisis of legitimacy. Understanding the Syria conflict as a proxy war only in terms of the involvement of different regional and international actors disregards the role of the Ba' athist regime's enforced ideation to maintain authority and legitimacy. Consequently, if we are to fully understand how the regime has maintained its stability, I believe that, in addition to explaining the military, political, and economic dimensions of the Syrian conflict, we must also appreciate how religion has been constructed in official political discourse and how its use helps to legitimize the Ba' athist state. The analysis of public political discourse as a methodological approach reveals how some forms of knowledge are privileged over others, how identity is constructed and maintained, how power is legitimized, how political violence and repressive security measures are normalized, and, in this case, how social and political consensus is produced and reproduced ideationally. Political discourses are not neutral reflections of social and political reality; rather, they form part of that reality - they have a reality-making effect. In this sense, this article critically explores the relationship between religion and political legitimacy in Syria.

The broad political question that shapes this inquiry is: what role does the employment of religious rhetoric in official political discourse play in reconfiguring a new national identity in post-2011 Syria?

To understand the relationship between state and religion, the construction of ideology since the creation of Syria as a nation-state in the 20th century needs to be closely analysed. While the creation of the modern Syrian state has appropriated a national ideology in an attempt to create a connection among its ethnically, religiously and racially heterogeneous subjects, 
this emerged nationalism is a manifestation of a state that is apparently very advanced and officially secular (Wedeen, 1999: 16). ${ }^{1}$ Article 8 of the 1973 Permanent Constitution affirms that the Socialist Ba'ath Party is the sole leading party of the state and society. While Ba'athism, as an intrinsically secular ideology, has been the most dominant national ideology in modern Syrian history, the Ba' athist regime under Hafez al-Assad made significant religious concessions, such as adding the constitutional requirement that the president be a Muslim and that Islamic fiqh constitutes the source of legislation.

Although these religious concessions reveal the state's interest in co-opting religious institutions, secularism was still the official state rhetoric. However, in the post-2011 uprising, President Bashar al-Assad has adapted a new national rhetoric that posits religious faith (imān) as the main identifier of national belonging and identity. ${ }^{2}$

This sacrifice of secularism in the aftermath of the uprising not only highlights the crisis of legitimacy currently being experienced by the regime but, more importantly, also elucidates how constructing a Ba'athified version of religious belief acts as a security tool against political dissidence. I define 'Ba'athified' as a configuration of the 'revolutionized' and 'progressive'3 notion of Islamic faith that focuses on aligning with Assad's views of the uprising. Consequently, my definition of Ba'athism does not entail its historical, ideological, and political genesis since the 1940s but, rather, tackles its evolution and how it has become restricted to supporting the Assad family since the 1980s with the adaptation of a Ba'athified religious rhetoric that ensures the survival of the Ba'athist state by sacrificing secularism. This

\footnotetext{
${ }^{1}$ Wedeen, Lisa. 1999. Ambiguities of Domination: Politics, Rhetoric, and Symbols in Contemporary Syria. Chicago, IL and London: University of Chicago Press.

${ }^{2}$ The employment of religious rhetoric by the Ba' ath regime can be traced to after the invasion of Iraq in 2003 and the assassination of Rafiq al-Hariri in 2005, but these instances were more of using religion as an accessory to garner support in times of isolation imposed on Syria. Since 2011, it is more a case of utilizing religion as a state-led strategy and part of conflict resolution and a security plan. See Pierret, Thomas. 2013. Religion and State in Syria. Cambridge: Cambridge University Press.

${ }^{3}$ The use of these two terms is taken from Bashar al-Assad's speech on 25 August 2011.
} 
propagation of a personalistic rule in Syria substitutes Ba'athism as the base of its ideological foundation. As such, this regulation of religious authority in the Syrian uprising since 2011 has been aimed at ensuring the survival of the regime by mobilizing this conditioned and constructed version of $\mathrm{Ba}$ 'athified religious belief as being synonymous with patriotism and national belonging.

In attempting to understand the relationship between the $\mathrm{Ba}$ athist state and religion in Syria, it is important to note that this has pursued different historical trajectories, ranging from confrontation to co-optation (Pierret, 2014). ${ }^{4}$ However, despite the importance of looking at the 'reformulation' of religious discourse by the state in the post-2011 uprising for reasons relating to legitimacy and survival (Khatib, 2016; 2019), ${ }^{5,6}$ this article's point of departure lies in updating Pierret's created spectrum of state-religion relationship ranging from confrontation to co-optation. I argue that in post 2011 conflict, the new state-religion spectrum is conflation. This article is closely investigating the state's strategy of propagating a so-called 'modernized', 'moderated', and 'purified' version of Islam. ${ }^{7}$ To mark the adaptation in the state's deployment of religious rhetoric after $2011,{ }^{8} \mathrm{I}$ argue that the $\mathrm{Ba}$ ' athist regime has relied on religion to sustain its authoritarian rule.

Here the state-religion relationship goes beyond co-optation to intense monopolization in times of political uncertainty. This appropriation of state-religion boundaries highlights not

\footnotetext{
${ }^{4}$ Pierret, Thomas. 2014. 'The Syrian Ba' ath Party and Sunni Islam: Conflicts and Connivance.' Middle East Brief 77, Crown Center for Middle East Studies, Brandeis University, February.

${ }^{5}$ Khatib, Line. 2016. 'More Religious Yet Still Secular? The Shifting Relationship Between the Secular and the Religious in Syria.' Syria Studies 8 (1): 40-60.

${ }^{6}$ Khatib, Line. 2019. 'Syria, Saudi Arabia, the U.A.E. and Qatar: the "sectarianization" of the Syrian conflict and undermining of democratization in the region.' British Journal of Middle Eastern Studies 46 (3): 385-403, DOI: $10.1080 / 13530194.2017 .1408456$

${ }^{7}$ Terms used by Assad in the speech analysed in the second part of this article.

${ }^{8}$ Suffice to note that the analysis in the paper will be limited to a single speech, which marks the shift in regime's strategy to complete monopolisation of religious institutions after 2011.
} 
only the blurred lines between the two, but the ultimate endorsement and conflation by the religious sector of the regime's discourse. This article asks the following primary question:

- What role does the Ba'athification of religion play in maintaining the survival of the Ba'athist regime?

The process of deconstructing the deployment of religious rhetoric by Bashar al-Assad provides an insight into the newly constructed social contract between the $\mathrm{Ba}$ 'athist regime and the Syrian Sunni majority. Thus, the article aims to highlight the reconfiguration of statereligion relations and the adaptation of a supporting rhetoric that juxtaposes the survival of the nation with that of Assad himself.

Key to the focus of this article is a close analysis of President Bashar al-Assad's speech of August 25, 2011. While there has been a plethora of studies tackling the question of statereligion relations in Syria both before and since 2011, there has been no comprehensive analysis of how religious belief is employed in political discourse. While this investigation of the relationship between religion and political discourse in the Arab region is underrepresented, the topic has been thoroughly investigated in the US context, with many studies of the impact of religious rhetoric in speeches by various US presidents (Hughes, 2019; Balmer, 2008; Campbell, 1990). ${ }^{9,10,11}$ This article aims to fill the gap in how religious rhetoric is being employed by a secular state with particular focus on Syria in the current political turmoil.

This research uses content analysis to study the presidential speech of August 2011 that marks the state's early response to the uprising and the strategic decision to turn to religious

\footnotetext{
${ }^{9}$ Hughes, Ceri. 2019. 'The God Card: Strategic Employment of Religious Language in U.S. Presidential Discourse.' International Journal of Communication 13: 528-549

${ }^{10}$ Balmer, R. H. 2008. God in the White House: A history-How faith shaped the presidency from John F. Kennedy to George W. Bush. New York, NY: HarperCollins.

${ }^{11}$ Campbell, K. K. and Jamieson, K. H. 1990. Deeds done in words: Presidential rhetoric and the genres of governance. Chicago, IL: University of Chicago Press.
} 
discourse for its survival. Previous research has typically concentrated on the complex relationship between the $\mathrm{Ba}$ 'athist state and religion, documenting phases of confrontation, cooptation, and rapprochement. ${ }^{12}$ However, this research closely examines the adoption of religious rhetoric by President Bashar al-Assad and the state's premeditated attempt to Ba'athify Islam. This will be further explored by examining the ulama's response to the crisis and Assad's Ba'athification of Islam by creating a 'Jurisprudence of Crisis', in which Assad's words were explicitly and forcefully implemented.

The first section aims to explore the question of legitimacy in the Syrian context in relation to the complex role of nationalism and religion in garnering legitimacy for the new Ba' athist regime since its rise to power in 1970. This section focuses on exploring the different phases and trajectories of secularism in the Syrian context, employing Khatib's conceptualization of secularism from a culturally accepted ideology to a regime-imposed system and latterly to a narrative that accommodates religion as an indispensable part of secularism. This section will critique some of these phases and argue that, in the post-2011 uprising, the relationship between secularism and religion is not only a matter of reformulation of the religious discourse but a perpetuation of the $\mathrm{Ba}$ athified version of Islam that sacrifices secularism. It will also highlight the increase in religious discourse. The article then moves on to interrogate the strategic deployment of religious rhetoric in public political discourse by deconstructing Bashar alAssad's speech.

What is clear, however, is that the adaptation of religious rhetoric during the Syrian conflict has produced a façade of legitimacy for Assad. The reconfiguration of state-religion patronage reflects the emergence of a pre-established alliance with a newly adapted religious rhetoric that hinges on propagating personalism as a form of authoritarian survival. The following sections

\footnotetext{
${ }^{12}$ Pierret, 2013. Religion and State in Syria.
} 
argue that the Ba'athist regime's reaction to the people's demands was creating distinct forms of religious nationalism that are conflated with $\mathrm{Ba}$ athism. This newly constructed version of Islam will be interrogated through a close deciphering of notions of patriotism, national belonging, and religious belief in President Assad's first speech to religious ulama. My choice to analyse this speech stems from its importance in laying out the state's official shift not only in how sectarianism, secularity, and Islam have been conceptualized and constructed by the Ba'athist regime, but also its instrumentalization of these constructed notions to create a homogenized, crossover, synonymized, and conflated perception of religious belief and support for the regime.

This will be realized by looking closely at the official discourse used by Bashar al-Assad to construct the notion and practice of 'support for and loyalty to the regime' as a compulsory religious practice that is needed to realize one's morality. This synonymization and conflation constructed since 2011 between supporting Bashar al-Assad and being a pious Muslim requires a deep understanding of the different trajectories and phases undergone between religion and nationalism since the creation of Syria as a nation-state.

\section{Nationalism, religion, and the crisis of legitimacy}

Legitimacy is a complex and multilayered concept that has different applications depending on the context being considered. T.H. Rigby argues that legitimacy is best understood as:

The expectation of political authorities that people will comply with their demands ... based not only on such considerations as the latter's fear of punishment, hope of reward, habit or apathy, but also on the notion that they have the right to make such demands. This notion both 
inheres, explicitly or implicitly, in the claims of the authorities, and is reciprocated, to a greater or lesser extent, in the minds of those whom compliance is demanded. ${ }^{13}$

Rigby further demonstrates that the notion of political order is intimately linked to the nature of political consolidation. Brooker $(2013)^{14}$ states that one approach to consolidation in non-democratic regimes can be by propagating 'patriotic claims' stating that the new regime is a necessary response to worse possible outcomes such as separation, civil war, or revolution (109). Once the first stage has been fulfilled, another possible approach by the regime is to 'strengthen its control over society and state machinery'. This second approach can be translated as an alternative should the people perceive that claims to legitimacy in the first approach are weak (Brooker, 2013: 107). These two approaches fit the Syrian case before and since the 2011 uprising, where nationalist sentiments were propagated in the early phase of the consolidation of the Syrian state and the second approach was implemented by the regime to further enhance its politicization of and control over society.

In recent years the study of legitimacy has become increasingly popular in the Syrian context. Although the notion of legitimacy has been linked with the word 'crisis', this term not only means the current Syrian crisis but also refers to the 'legitimacy crisis' that was concomitant with the coup d'état led by Hafez al-Assad in 1970. The fundamental question that dominates the political landscape in an authoritarian regime is how the ruler constructs a convincing legitimacy beyond the material use of military force. In the Syrian context, maintaining legitimacy has not been limited to material factors encompassing reliance on coercion, security forces, and fear. Rather, the Ba'athist state has substantiated its right to rule

\footnotetext{
${ }^{13}$ Rigby, T.H. 1982. 'Introduction: Political Legitimacy, Weber and Communist Mono-organisational Systems.' In Political Legitimation in Communist States, edited by T.H. Rigby and F. Feher. London: Macmillan, p. 1.

14 Brooker, Paul. 2013. Non-democratic regimes. London: Palgrave Macmillan.
} 
using various resources, both ideological and religious. For the purpose of this article, this section will focus on how using ideology and religion has maintained legitimacy in Syria.

The enigma of understanding legitimacy in the Syrian context entails asking a simple question: Why was Ba'athism not enough to maintain legitimacy? Hafez al-Assad's relentless efforts to mobilize a secular national ideology to form a supporting base included applying Ba'athist principles (Milton-Edwards, 2006: 417). ${ }^{15}$ As such, in an ethnically divided state in which religious and ethnic affiliations are intertwined, the state has reinforced a secular national ideology to create a homogeneous sense of nationhood. The difficulty in articulating a Syrian national identity stems from the various minority sects including Armenians, Assyrians, Druze, Palestinians, Kurds, Yazidi, Mhallami, Arab Christians, Mandaeans, Turkmens, and Greeks. Given the mosaic nature of Syrian society, nationalism is considered the major force in shaping its structure and stability. To override this ethnic and sectarian identity of such groups for the constructed supra-nationalist one manifested in Ba'athism, a state-based nationalism determines the designation of people's sense of identity and belonging.

This paper therefore starts with the conception that the early formation of the nation-state in Syria includes an interaction with a national ideology imposed from above. To borrow Hinnebusch's words on the creation of Syria as a state, it is likened to 'a "Bonapartist" regime - a postrevolutionary authoritarian regime standing "above" classes and presiding over the formation of a strong new state and the transition from a feudal order to a more complex society' (1989: 302). ${ }^{16}$ The difficulty in legitimizing its circumscribed boundaries is faced particularly by the Syrian state in its continuous attempt to justify the need to manufacture a

\footnotetext{
${ }^{15}$ Milton-Edwards, Beverley. 2006. Contemporary Politics in the Middle East. Cambridge: Polity Press.

${ }^{16}$ Hinnebusch, Raymond A. 1989. Peasant and Bureaucracy in Ba 'athist Syria: The Political Economy of Rural Development. Boulder, CO: Westview Press.
} 
state-centric national consciousness, and this was achieved through adopting a secular national ideology, i.e. Ba'athism.

Despite the official secular nature of Ba'athism, in the last four decades the $\mathrm{Ba}$ 'athist state has adapted this secularity by establishing a co-opted relationship with the religious sector. Given the different phases and trajectories linked to secularism in Syria, I adopt Khatib's notion of the various phases, changes, and trajectories that the relationship between secularism and religion has gone through in the country. This paper, however, attempts to go beyond what Khatib called the 'reformulation of religious discourse' to conceptualize the shift in the official religious discourse used by Assad after the 2011 uprising as the 'Ba'athification' of Islam. Before explaining why I use 'Ba'athification' rather than 'nationalization', I will list the different phases of secularism in Syrian history as outlined by Khatib.

In the first phase, Khatib believes the emergence of secularism in Syria can be attributed to a number of factors that contributed to embracing secularism by both the Syrian intelligentsia and the people. These included the popular desire to break away from the past, manifested in deserting the Ottoman political system that relied on religion as the main source of legitimacy; and the direct encounter with and exposure to the French political system under the Mandate, which in turn made secularism an accepted ideology in which to frame the Syrian political landscape in the post-colonial era as a reaction to the repressive policies of Ottoman rule and a way to break with the past. This leads us to explore the origin of secularism in Syria prior to the ascendance of the Ba' athist regime in the 1970s, which had its roots in the national ideology that was embraced by most known Syrian ideologues (Saba', 2005: 270). ${ }^{17}$ As Salem affirms, the concept of nationalism that emerged between the 1950s and 1960s shows a 'devotion to the

\footnotetext{
${ }^{17}$ Saba' referred to al-Arsuzi and Aflaq as 'the knights of the Ba'ath Party'.
} 
emanation in the spirit of modern Western nationalism' (1994: 49). ${ }^{18}$ Khatib's notion of an 'existing secular culture' in Syria is not a result of an imposed national ideology from above like Ba'athism but, rather, an ideology that is concomitant with certain historical, intellectual, and political sentiments.

However, what is really missed in Khatib's argument is that secularism should not be used as a homogeneous term; rather, the secularism that emerged in the Syrian constitutions prior to the ascendance of the Ba'ath Party in 1970 is quite different from how Ba'athism mobilized and used it. In other words, after the ascendance of Hafez al-Assad secularism became an ideology imposed from above and was mainly used to legitimize the rule of the minority. This perception of secularism in the Arab world resonates with Cesari's ${ }^{19}$ and Brown's ${ }^{20}$ argument that the process of secularization in the Arab world does not entail the common notion of separating the state from religious institutions. Rather, most Arab states have sought to employ religious rhetoric in the public space for purposes related to legitimacy and authority.

The second phase is identified in the role played by ulama in consolidating the authority of the Ba'athist regime in the mid-1970s. It encompasses the revival of religious rhetoric in a way that accommodates the $\mathrm{Ba}^{\prime}$ athist version of secularism. It is in this phase that the story of the crisis of legitimacy and the need to co-opt the religious sector was conveyed in the first Permanent Constitution under Hafez al-Assad's rule. The 1973 Constitution gave him farreaching powers, but the omission of the article that specifies Islam as the official religion of the president sparked organized protests in major Syrian cities. Assad's attempt to remove this

\footnotetext{
${ }^{18}$ Salem, Paul. 1994. Bitter Legacy: Ideology and Politics in the Arab World. Syracuse, NY: Syracuse University Press.

${ }^{19}$ Cesari, Jocelyne. 2014. The Awakening of Muslim Democracy: Religion, Modernity and the State. Cambridge: Cambridge University Press.

${ }^{20}$ Brown, Nathan J. 2017. 'Official Islam in the Arab World: The Contest for Religious Authority.' Washington DC: Carnegie Endowment for International Peace. http://carnegieendowment.org/2017/05/11/official-islam-inarab- world-contest-for-religious-authority-pub-69929.
} 
provision signified his attempt to legitimize his authority given that he comes from a minority sect. This change to the Constitution meant that Hafez al-Assad was attempting to implement secular rule, yet from his early days in office he escaped this confrontation with the majority Sunnis by asking a Shi'ite 'Álim to consider the Alawite sect as Muslims. This proves that Assad was reluctant to confront the Sunni majority ${ }^{21}$ and, rather, attempted to construct popular support for his rule. Despite using the Ba'ath Party as a vehicle to ensure his social, cultural, and political control, Assad also employed a religious supporting rhetoric by co-opting a religious institution to maintain his legitimacy and authority.

However, the co-optation of the religious sector was adopted as a strategy after the fierce confrontation between the Ba'athist state and the Muslim Brotherhood in the 1970s and 1980s. ${ }^{22}$ While the mainstream analysis of the Ba'athist-Sunni relationship has concentrated on the emergence of political Islam in Syria in the form of the Muslim Brotherhood (Pierret, 2014: 1-2), this internal rehabilitation of the regime was part of Hafez al-Assad's policy to consolidate his rule in the 1980s and 1990s, specifically after the violent crackdown of the Hama riots in 1982 that resulted in the death of between 10,000 and 40,000 people. The rise of this antagonism between the regime and the Muslim Brotherhood impacted the evolution of sub-political identities within Syrian communities. This led to the rise of a favoured Sunni rule within the Ba'athist regime that believed an increasingly politicized Muslim Brotherhood would threaten their approach as a moderate Sufi version of Islam. However, this violent confrontation between the regime and the Brotherhood resulted in the co-optation of other groups of Sunni ulama.

It is therefore important to know that, while the $\mathrm{Ba}$ 'athist regime violently crushed the Muslim Brotherhood and co-opted other religious ulama, it also implemented a policy of

\footnotetext{
${ }^{21}$ By 'Sunni majority' I mean those Sunnis who did not participate in the protests.

${ }^{22}$ Cesari. The Awakening of Muslim Democracy.
} 
'neutralization' of the Sunni religious elite (Pierret, 2014: 3). This policy of excluding the majority of Sunni ulama was selective and did not extend to all types of religious school in Syria. Rather, a well-constructed partnership developed between the $\mathrm{Ba}$ 'athist regime and other types of Sunni school in Damascus. This partnership evolved in the aftermath of the violent eradication of the Muslim Brotherhood, which opened the path for other religious schools to build a strong relationship with the regime. Hence, it is important to note that the Ba'athist regime's violent response to the Brotherhood was countered with conciliatory gestures towards some prestigious Sunni ulama. These took the form of nationalizing religious institutions through personalising them by renaming a mosque with the name of the Ba'athist president, Hafez al-Assad.

At the same time, Hafez al-Assad benefited from the long-standing rivalry between the Muslim Brotherhood and Sufi Islam, and he used this factionalism to strengthen his rule and legitimize his authority. Another issue that played to his benefit was that the Brotherhood's militarization did not have mass appeal in Syria, given that the chaotic period that preceded him meant people were searching for strong leadership to bring stability and ensure the availability of basic goods for Syrians. ${ }^{23}$ One tool to garner legitimacy in the early years of Hafez al-Assad's rule was the selective nationalization of some religious institutions. The bestknown of these was the Abu al-Nour Islamic Centre, led by the Grand Mufti, Ahmad Kaftaru. When Hafez al-Assad began his rise to power in 1963, he had to find social and cultural avenues to cultivate support from the Sunni majority. However, he had a hostile relationship with some widely recognised Sunni ulama, who opposed his military coup and militaristic style. Instead, he constructed an alliance with particular Sunni schools that employed a supportive religious rhetoric by co-opting a religious institution that verified his legitimacy and authority. This

\footnotetext{
${ }^{23}$ Hashemi, Nader. 2014. 'Rethinking religion and political legitimacy across the Islam-West divide.' Philosophy \& Social Criticism, 40 (4-5): 439-447 [444].
} 
compromise was necessarily with an Islamic school that showed no desire to share power with the $\mathrm{Ba}$ 'ath Party but sought, rather, to secure more space to spread its moral and religious ethos. A track record of strong connections between the Sufi community and state apparatuses in the Middle East can be traced back to the 12th century under Ottoman rule (Trimingham, 1998: 7$10) .^{24}$

What followed was a long process of endorsement of the regime's legitimacy through securing a deal with Sufi Islam in Syria. As Pinto argues:

After the disaster that marked the confrontation with the 'Islamic Front,' the Ba' thist regime changed its policy towards the role of Islam in social life, shifting from confrontational secularizing measures towards an accommodating relationship in which certain forms of Islam were discreetly sponsored and others were repressed or tightly controlled. (Pinto, 2003: $7)^{25}$

It was a constructed contract premised on the state supporting these religious institutions while maintaining close control over their rhetoric and practices in exchange for a wider social base (Perthes, 1995: 188). ${ }^{26}$

It is in this phase that the Ba'athist state under Hafez al-Assad chose to accommodate Sufism as the salient representation of Islam, knowing that promoting this strand would ensure the loyalty and submission of the Sunni majority. This political incorporation of Sufism into Ba'athist policy was achieved through the empowering of Sheikh Ahmed Kuftaru, the Grand Mufti (Habash, 1996; Pinto, 2003: 7). Kuftariyya had widespread popularity and support among the Damascus middle class, as well as among the new bourgeoisie that developed from

\footnotetext{
${ }^{24}$ Trimingham, J. 1998. The Sufi Orders in Islam. Oxford: Oxford University Press.

${ }^{25}$ Pinto, Paulo. 2003. 'Dangerous Liaisons: Sufism and the State in Syria.' In Crossing Boundaries: From Syria to Slovakia, edited by S. Jakelic and J. Varsoke. Vienna: IWM Junior Visiting Fellows' Conferences, Vol. 14.

${ }^{26}$ Perthes, Volker. 1995. The Political Economy of Syria under Asad. London: I.B. Tauris.
} 
economic privileges acquired through personal ties with the state apparatus (Pinto, 2003: 7). As Khatib argues:

Syrian secularism is no longer the hard line, uncompromising ideology that the Ba'th party intellectuals once promoted, but rather a more complex ideology that is transforming Syrian society and pulling it in many directions that cannot simply be categorized as 'religious' or 'secular'. ${ }^{27}$

According to Khatib, this blurred line between describing Syrian society as religious or secular can be attributed not only to the complex relationship between secularism and religion in Syria, but also to the regime's reformulation of religion to accommodate the official secular vision of the state. This brings us to the third phase, which started with the outbreak of the uprising in 2011 and which Khatib called 'reformulation'. Khatib argues that in this phase there is a process of 'Islamizing' the country:

More recently, it has changed again primarily as a result of a re-evaluation and re-valuing of the understanding of religion that informed the previous secular model. In this newest version, religiosity regains its meaningful place within society but a new facet of the religious that essentially perpetuates secularism is promoted. (Khatib, 2016: 42)

Pierret and Khatib agree that this re-Islamization of Syrian society was an attempt to manipulate and mobilize the religious discourse for more control and policing by the state (Khatib, 2016: 43). In particular, Khatib refers to this Islamization of the official discourse as something endorsed by the well-known ulama mobilized by the state, arguing that, despite this endorsed religionization of society, the young would still choose a secular polity (Khatib, 2016: 59). However, I view this Islamization not as something to be approached from the side of the ulama; rather, the way in which this adoption of religious discourse by the president revealed

${ }^{27}$ Khatib. 2016. 'More Religious, Yet Still Secular?', p. 41. 
a new phase in Syrian history that marks a departure from secularism. Moreover, I argue that what accompanied this 'reformulation' of religious discourse was the designation of new boundaries between the state and religion.

It is important to note that Khatib's account of this phase is restricted to her analysis of the Islamization of Syrian society up to March 2011. While the instrumentalization of religion as a cultural basis for Syrian society and part of the regime's national project by the Ba' ath regime up to 2010 was normal practice, the official secularity of the state has always been the determining factor of imposed national identity. ${ }^{28}$ However, this juxtaposition between maintaining the official secularity of the Syrian identity by the regime and simultaneously Islamizing the public discourse or taking a lenient approach towards religion to ensure legitimacy before 2011 has come to an end and marks the departure from official secularity to more official religionization. What is missing is that, beyond the instrumentalization of religion and the redrawing of boundaries between religion and the state since 2011 , one should note that the newly adapted religious discourse is an attempt to propagate a foundational basis for religious faith (imān) that constructs a more fixed (Ba'athified) interpretation of Islam. This new religious discourse essentializes a particular invention of a 'Mohammedan' message that is identified and shaped by the $\mathrm{Ba}^{\prime}$ athist regime and not only religionizes or Islamizes society but conflates and synonymizes being a patriot with being a religious believer.

\section{Religion as a source of legitimacy since 2011}

The role of religion in the 2011 Syrian uprising has been a recurring theme in many studies. Some compare the role of mosques in this uprising to that in the 1980s, while others focus on

\footnotetext{
${ }^{28}$ See Pinto, 2011, p. 192. In a Charlie Rose interview with Bashar al-Assad in May 2010, Assad refers to the challenges he is facing in maintaining secularity as the main definer of Syrian society.
} 
relating the ulama's response to this uprising with the narrative they used in the earlier one. ${ }^{29}$ Some other studies focus on the role of religion in spurring sectarianism in the post-2011 uprising (see Philips, 2015). ${ }^{30}$ Perhaps an indicator of the need to understand the relationship between religion and Bashar al-Assad's survival is the way in which religion has been given greater benefits and broader public space in the official state narrative since 2011 . This can be seen from the issue by the Syrian government of a religious decree that gives more influence and autonomy to religious institutions. Decree no. 16 has been widely criticized by both Assad loyalists and opponents, 'decried as an attempt to strengthen the influence of conservative Islam on Syrian society' (Rose, 2018). ${ }^{31}$ More importantly, reactions on social media considered this religious decree a government betrayal of the official secularity of the Syrian state and an invitation to Islamic extremism. The decree, signed by Bashar al-Assad, stipulates that the Ministry of Religious Endowments (Awqaf) is responsible for managing the various religious institutions associated with Sunni Islam. ${ }^{32}$ However, this is understood by both loyalists and opponents as giving legal autonomy to the ministry, thereby channelling he state's powers to oversee and dictate what is acceptable and not acceptable when it comes to religious behaviour in Syria.

Contrary to the 'relative economic and institutional autonomy' that the ulama were enjoying before 2011 as they were not part of the state apparatus (Pierret, 2013: 15), this decree restricts their authority and furthers the state's powers and dominance over religious institutions and their rhetoric. In other words, it enhances the state's measures in policing

\footnotetext{
${ }^{29}$ Qureshi, Jawad. 2012. 'The Discourses of the Damascene Sunni Ulama during the 2011 Revolution.' In Line Khatib, Raphaël Lefèvre \& Jawad Qureshi, State and Islam in Ba'athist Syria: Confrontation or Co-optation? 59-90. Fife, Scotland: University of St Andrews Centre for Syrian Studies.

${ }^{30}$ Phillips, Christopher. 2015. 'Sectarianism and conflict in Syria.' Third World Quarterly, 36 (2): 357-376

${ }^{31}$ Rose, Sunniva. 2018. 'Syria’s new religious bill angers Assad loyalists.' The National, October 4. https://www.thenational.ae/world/mena/syria-s-new-religious-bill-angers-assad-loyalists-1.777378.

${ }^{32}$ Al-Kassir, Azzam. 2018. 'Formalizing Regime Control over Syrian Religious Affairs.' Carnegie Endowment for International Peace, November 14; Rifai, Laila. 2018. 'Syria's Regime has Given Fatah Islamic Institute Influence, but at what cost?' Carnegie Middle East Center, December 13.
} 
Syrian society by conflating religion with security and national unity. This further constitutes a departure from the 'personalised and fixist conception of the transmission of religious knowledge' (Pierret, 2013: 33) in the early phase of Ba' athist rule.

It must be noted that the assumption constructed around how this religious decree is widely perceived in the mainstream media stems from a failure to understand the importance of analysing the religious rhetoric used by Bashar al-Assad after the 2011 uprising. There is thus a lack of understanding about the real implications of this decree, which deals not with ending secularity but, rather, propagating a new conception of Islam as defined and articulated by the Ba' athist state. In the words of the Minister of Awqaf, Dr Mohammad Abdul-Sattar al-Sayyed, what is overlooked by this mounting criticism is that the purpose of the decree is to redefine what Islam is by propagating the state's definition of moderate Islam as a tool for fighting extremism and terrorism. ${ }^{33}$

\section{Assad's speech of August 25, 2011: Setting out the general landscape}

This speech was delivered at the first official meeting between President Bashar al-Assad and religious ulama after mass street protests broke out in Syria in March 2011. Its importance lies in setting out how the official narrative adopted by the Ba'athist regime conceptualized the conflict in terms of its causes, the state's approach to dealing with it, and the role assigned to ulama by the state. It is worth noting that Assad's tone is somewhat conciliatory. It shows the state's need to mobilize religious rhetoric in order to employ ulama in conflict resolution as an initial process for the later construction of those who opposed the regime as securitized objects.

\footnotetext{
${ }^{33}$ There is an abundance of interviews and lectures in which the Minister of Awqaf extensively explores the need to reform the religious discourse in light of Bashar al-Assad's instructions and recommendations.
} 
President Assad starts by clarifying that, while the meeting was scheduled to celebrate the coming of Ramadan, recent events had reframed the setting. Assad declares that he will use the opportunity of celebrating Ramadan and meeting the ulama to talk about latest developments in the national crisis. His speech contains three main elements: defining the national crisis by asking questions about its causes and the benefits that could be drawn since its start in March 2011; the role of ulama in challenging sectarianism; and identifying the difference between being a true believer and being a true patriot.

\section{The official conceptualization of the conflict}

'How can we learn from this crisis? What is the lesson that can be drawn from what has happened in Syria?'

Assad starts by greeting the ulama for Ramadan but then immediately asks rhetorically how can both the religious sector and the state benefit from the national crisis. He insists that there is a need to learn from what had happened. Assad further points to how 'the blood that has been spilled has enabled the state to see things more clearly'. The clarity to which Assad refers comes from another term used in the speech: the 'fogginess' ( $d b \bar{a} b)$ that, in his words, 'obstructed the state's vision from communicating with the Syrian people'. Assad's tone shows almost a shy admission of a lack of understanding on the state's part. In particular, the reference to the 'foggy perception' - in other words, the lack of a clear vision in Syrian society - invites questions about how the official rhetoric conceptualizes and intends to frame the conflict.

'We cannot go back in time.' 
In the process of defining what might have caused the crisis, Assad's tone suggests that the regime recognizes that what has been done cannot be undone. This is in part an implicit reference to the mistakes committed by the security forces in the violent crackdown on the peaceful demonstrations. Assad confirms that there are lessons to be learned from what has happened.

While using this conciliatory tone, Assad turns to the logicalization of the crisis by alluding to factors ranging from a weak economy and overdue reforms to cultural and social problems. Yet, right from the beginning Assad points to other underlying causes by situating religious belief at the heart of the problem. This can be seen in his reference to events as a 'crisis of morality' ('azmat 'akhlaq). This conceptualization reveals an early attempt to absolve state policies of any responsibility for fuelling the urgent demands of protests against the Ba' athist state.

This essentialization of the conflict is further manifested in how he associates religious disbelief with political dissidence:

When we see someone going to the mosque and he does not know how to pray but then participates in protests against the state knowing that such protests and slogans are not only against the state but rather against religion ...

Assad's words are exclusivist as they draw a parallel between being a true believer who supports the regime and those non-believers who use Allah's name for their own personal gain. He says that if some state officials committed injustices against citizens, this is also about lack of morality rather than the state's responsibility.

'Religion came to complete morals.' 
In a further attempt to justify dependence on ulama for responsibility in fighting political dissidence, Assad emphasized the overlap between citizenship, true belief, and entitlement to national belonging. This further demonstrates the process of Ba'athification of religious belief after the uprising began. This was complemented by reciting the Quranic verse 'And hold on to all the rope of Allah and do not divide', which marks another important deviation from secularism. Assad's emphasis on challenging division in Syrian society by empowering religious belief (i.e. its Ba'athification) is another instance of him employing religion as a security tool from the early days of the conflict.

\section{Islamization of nationalism}

The second important pillar in the speech entails Islamizing nationalism. This marks not cooptation of religion but, rather, a deviation from secular nationalism. This is clearly manifested in Bashar al-Assad's official and emphatic order to hold ulama responsible for what he called 'national chaos and anarchy'. By considering ulama as security agents and state actors to resolve the conflict, the boundaries between the religious sector and the state are no longer visible and a new stage of merging and conflation has been endorsed.

Traces of Islamization in the speech are clear in the way President Assad uses the lack of understanding of the difference between ulama and extremists as part of the explanation for the cause of the conflict. This not only securitizes Sunni ulama and depicts those who do not support Assad as extremists and terrorists, but also consecrates Islam as a source of national unity and security. Assad further points to those ulama who stood with the uprising as manipulating religion for their own personal gain.

In this speech, Assad also lists the 'benefits' of the conflict, as it revealed the 'rust' (sada') in Syrian society. By using this analogy, Assad further emphasizes that this uncovered the 
extent to which the Syrian people (al-shari) are faithful 'believers' (mu'mnīn). He claims this discovered faithfulness is the best form of patriotism at the time. This depiction of religious faith as overlapping with expressed patriotism emphasizes the departure from secularism in official discourse.

This is further manifested in the comparison between religious belief and patriotism as Assad emphasizes the incompatibility of being a true believer and not being a patriot. This connection not only glorifies religion and normalizes sacrifice (as dying for the nation becomes sanctified and sacred), but also eliminates the universal nature of religion and localizes it to fit the political message of the state.

The explicit deviation from secularism comes in the president's assertion that 'religion and nationalism are counterparts'. With this association, Assad further affirms that it is the only way to fight sectarianism: the spur of sectarianism is due to moral failure and to long-standing neglect of the importance of associating religion with nationalism. This comes with his fierce attack against those ulama who did not say that protesting was a sin. Hence, sectarianism becomes not about the rivalry between Sunni and Shi'a but about political dissidence and disobedience. Assad goes further, making a rigid categorization of those who participated in the protests and those who stayed silent, referring to the former as 'sectarian' and to the latter as patriots. This categorization not only builds on his attempt to sectarianize the conflict but also homogenizes protest as a sinful act. This conceptualization emanates from the early days of the uprising, when mosques ${ }^{34}$ became sites of civil disobedience regardless of their religious, ethnic, or sectarian affiliations (see Hashemi and Postel, 2016; ${ }^{35}$ Qureshi, 2012) ${ }^{36}$ The role of

\footnotetext{
${ }^{34}$ One can argue that this crucial role of the mosque stems from the state's repressive measures against any mass gathering in the street; Friday prayers therefore became the only legitimate and possible way for protestors to gather and organize themselves.

${ }^{35}$ N. A. Hashemi and D. Postel (eds.), Sectarianization: Mapping the New Politics of the Middle East. London: Hurst Publishers, 2016.

36 'The Role of the Mosque in the Syrian Revolution'. Near East Quarterly. March 20, 2012.
} 
mosques in the Syrian uprising has been portrayed as embodying a political threat to the regime's order and authority. Repressive measures including direct military targeting or being stormed by security forces thus became some of the regime's policies to suppress any resurgence from the mosques.

In fact, the formal denunciation of secularism is explicitly manifested in Assad's reformulation of national identity and belonging. At this point, he is ostensibly speaking about the mistakes of adopting a secular national ideology. ${ }^{37}$ This reflection on the national ideology adopted since the 1970s is in line with his call to revive and activate what he called a 'modernized' interpretation of Islam. This activation and reconfiguration of religious identity as a substitute for the secular one serves as a tool of the state to garner support and legitimacy. Assad logicalizes this deviation from the secular ideology by stating:

Despite having a national ideology that propagates national unity, and this is propagated as part of political ideology and religious requirement, sectarianism still spreads. Sectarianism spreads when first our religious commitments weaken and then when the basis of our political unity ceases to exist.

According to Assad, reinforcing a religious nationalism is the first answer to the spur of sectarianism - completely contrary to how secularism was employed in the 1970s as a viable instrument to consolidate the rule of the minority. This is more evidence of denouncing secular nationalism and the previous state approach towards containing the heterogeneous nature of Syrian communities by obscuring one's sectarian identity rather than embracing it, which led to the rise of sub- and supra-state identities after the 2011 uprising. Assad concludes that the religious and political factors cannot be separated. He further states that, in order to defy the

\footnotetext{
${ }^{37}$ This might also be interpreted as a recognition of the regime's failure to impose secularism that attempted to homogenize identities by obscuring the plurality of Syrian communities. It can be read as the regime's reflection on how its previous approach of obscuring any sectarian affiliation or its prohibition of expressing one's sectarian identity was not about recognizing the mosaic nature of Syrian communities but, rather, contributed to the rise of sub- and supra-state identities.
} 
spread of sectarianism, we should focus on what binds us together and, while it is natural to disagree with each other, this disagreement must not lead us to division.

It is important to note that Assad is keen to reconstruct national belonging and identity and this is achieved through rethinking and reflecting on the old frames of what defines these notions. Assad chooses religion as the base on which to reconstruct national unity in the midst of the crisis. He identifies national belonging with following the message of Mohammed. It is not quite clear what he means by this and what religious school he intends. Rather, he states that this is an innovative path to religion, which should be followed and dictated by patriotic ulama to show their support for and love of the country. According to Assad, the modernization of religion is characterized by being 'Mohammedan'. He says this is like being a supporter of the $\mathrm{Ba}^{\prime}$ athist regime. It is at this point that religion becomes $\mathrm{Ba}$ 'athified.

Assad says that becoming 'Mohammedan' is intimately linked with how the contours of belonging are constructed, using the words 'We belong to Mohammed only', which creates a sense of collectivity by reconfiguring Mohammed as the binding force behind national unity that can challenge sectarianism. Assad sends a clear message to ulama that logical and rational understanding of religion does not exist in every citizen's mind, so the ulama's role is to ensure that the reconceptualization of religion comes from the mind and has a logical ('aqlani) interpretation.

This Ba'athification of Islam was necessary to hinder any instrumentalization of faith by the ulama, which could be used as a mobilizing force against the state. However, the firm grip on religious activities has gone beyond this, by insisting on the responsibility of ulama to call anyone protesting against the state an infidel. This process of Ba'athification entails homogenising the concept of what a 'moderate' (wasati) conception of Islam is by restricting it to the mere interpretation of these ulama, who are an extension of the Ba' athist state. 
As Assad's main concern is now to deter any political dissidence, he is exerting extra pressure on ulama to propagate the message that political protest is a form of religious sin. This strategy aims to contain Sunni ulama by holding them responsible for any political dissent. In this sense, containment becomes a necessary security strategy, rather than co-optation, coercion, or repression. To justify his reliance on ulama to resolve the conflict and maintain stability, Assad tries to religionize the conflict by ascribing any war crime committed by the security forces or the army attributed to soldiers' lack of morality to the ulama's failure to promote the 'right' interpretation of Islam, which in turn had created the 'crisis of morality'.

Assad seems more reliant on religious figures to fight both terrorism and sectarianism. His speech reveals that some ulama criticized the behaviour of the Syrian army, such as the bombing of Deir ez-Zor. Assad first states that the bombing could not have been carried out by the Syrian army and asserts that it was an act of terrorism to defame Syrian soldiers. However, he then changes tack, stating that, even if it had been carried out by a kafir (non-believer) and here it is important to note that he refers to offences by the Syrian army or security forces as kufr (non-belief) and not criminal acts - this was because of their lack of religion. This implicitly sends a message that the problem lies in a lack of understanding of what true religion is. Assad was asking the ulama to follow Mohammed's approach towards kafereen, which is teaching them and not fighting them. Assad is recruiting these religious figures to maintain stability through religious teaching and tawjeeh; we should depend on the mind and logical thinking. In his words: 'We need a balanced view; these mistakes come from a lack of morality, and therefore a lack of religion'. His narrative conceptualizes lack of religion as the main cause for political deviation; he synonymizes religion with morality. An act of protest is immoral, and therefore anti-religious.

Assad then goes on to emphasize the religiosity of the state, trying to denounce claims that, since the protests were led from the mosques, this created a sense that this was an attack against 
the state as it was anti-religious. Assad does not use the term 'secular' but, rather, 'antireligious'. He defends the state as not being anti-religious by mentioning what he had done to promote religion since he came to power. Assad's attempt to defend the state through himself was an explicit personification of it. In a way he was undermining the demands of the protesters and containing the problem as lying in a lack of religion. He starts to speak about his commitment to religion by mentioning his achievements in establishing a women's religious council, building on the Al-Nour Islamic Centre. He continues that Syria has politics that serve religion, unlike other Arab states where religion serves politics.

Assad then attacks the ulama, saying they are not doing enough to protect the state despite the state working to promote religion: 'You should propagate religion and morals'. Assad emphasizes the need to employ a systematic approach to promoting religion, as he warns religious men against abusing the 'rostrum' (minbar). ${ }^{38}$

Assad imbues his language with power by using a very carefully and deliberately constructed public discourse designed to demonize those ulama who did not propagate the authority of the $\mathrm{Ba}$ athist regime. He explicitly accuses them of exploiting the rostrum for their own personal gain. He went further, imploring religious ulama not to criticize the regime and stating that, even if this criticism was accurate and justified, it should be avoided as this might agitate the population and lead to direct confrontation with the police. Assad further warned the ulama that their intervention in politics — even if only by explaining what was happeningmight lead to their having 'blood on [their] hands, no matter which side led to this bloodshed' 39

The strategic employment of religion becomes official in Assad's explanation for the drafting of a new constitution in response to popular demand for changes. Assad strategically

\footnotetext{
${ }^{38}$ See Figure 4.

${ }^{39}$ See Figure 5.
} 
uses the 'God card' to muster support and legitimacy from ulama. This is evident in his statement about how, before changing the constitution, the state should preserve Sharia law. This implicitly presumed that the protector of Islam was the state and that the protesters were not only political dissidents but were also acting against Islam. His way of defending Ba' athism and Article 8 of the Permanent Constitution of 1973 — stating the Ba'ath Party's pre-eminent position-was to reconfigure the special relationship between Arabism and Islam in the Ba'athist ideology. While Ba'athism had always retained its secular character, Assad's reference to the unique and close relationship between Arabism and Islam confirmed his attempt to propagate and popularize a new Ba' athist national identity that formalized Islam as being fundamental.

Assad pledges to ulama that nothing would change in respect of religion and that the state still envisioned Islam as part of its strategic policy. This was about not only preserving the coopted relationship between the religious sector and the state, but also building a new patronage premised on configuring a conditioned version of Islam. This version is Ba'athified, as Assad defends Article 8 by indicating that the Syrian state in its current form is the only guarantee to maintain the primacy of Islam. By retaining the Ba' ath Party as the leading party of state and society, he implicitly states that it is through Ba'athism that Islam is protected and the rule of Sharia maintained. He is making the religious ulama fear any change. He goes on to mention the Constitution's articles preserving the religious identity of the state, confirming that, even with the reforms, these articles would not be changed.

Assad ends by focusing on the role of ulama in preserving national unity and protecting the nation from discord (fitna). This is done by adopting an intensified security rhetoric premised on depicting those who oppose the regime as an existential threat to the nation. $\mathrm{He}$ goes on to attribute the use of this securitized narrative to the pretext that 'everyone hates us now': 
The West hates us because we are nationalistic and Islamic. They might hate us for preserving our Arabism and our Islamic identity, but they usually protect those who preserve their principles.

Assad's intention to construct an antagonistic rhetoric is supported by building binary boundaries not only between those who support or oppose the regime, but also between Syria and the international order. The use of such security-based rhetoric is not new in the Syrian context, as the $\mathrm{Ba}^{\prime}$ athist regime has always relied on antagonism to maintain its legitimacy. However, what is novel about the current security approach is the ostensible deployment of religious rhetoric in public political discourse. It turns out that 'sectarianism' is used as a counter-revolutionary tool to consolidate authority.

The use of faith as a method of counter-revolution can also be seen in Assad's words: 'Our way to resistance is faith. Faith is security and safety.' Security and safety (Al-amin w al'amān) are two words often used by Assad as a way to recall the position those present were living in. He continues: 'Faith is the guarantee for our sons and daughters and for our afterlife'. Again, Assad implicitly states that the Ba' athist state can only be preserved through faith, and this faith is the way to paradise. This links the present with the unlimited and the unknown. Constructing this intertwined relationship between faith, security, and safety thus becomes Assad's strategy to safeguard his authoritarian rule.

\section{The Ministry of Awqaf and the creation of the 'Jurisprudence of Crisis'}

The importance of Assad's words is marked by their faithful implementation in the 'Jurisprudence of Crisis' published in 2014. Given the uncertainty of the political landscape, Assad wanted to ensure that monopolization encompassed full infiltration of the religious activities of all religious establishments in Syria. This is maintained through extensive 
subscription to Assad's words. ${ }^{40}$ Here we can see the difference between co-optation and coerced monopolization: the former implies some form of boundaries between state and religious sector, whereas the latter involves complete conflation.

Looking at the website of the Ministry of Awqaf, it is hard to believe that there is any separation between religion and the state in Syria. While one might argue that the Ba'athist regime has always maintained control over the religious sector, since 2011 this authoritativeness and control is masked by an entrenched religious rhetoric saturated with patriotic language placing religious faith at the heart of the national crisis. Assad's tone demonstrates a religiously influenced state that establishes complete hegemony over religious institutions. This is apparent in the infusion of religious rhetoric in the political agenda to resolve the conflict and the construction of a more coherent perception of Islamic faith premised on synonymizing love for the country with support for the regime. ${ }^{41}$

In this respect, one might argue that, compared to regime-religion relations before 2011, the Ba'athist state's attitude towards religion does not seem to have changed fundamentally. The regulation and control of religious manifestation in the public space has been the norm since the 1970s, but since the 2011 uprising the boundaries between the state and religion have become conflated.

This reconfiguration of the nature of the relationship is manifested in how the Ministry of Awqaf endorses Assad's speeches. As the website becomes a vital focus of political debate, the employment of Assad's words reflects the congruence between national belonging and

\footnotetext{
${ }^{40}$ A glance at the official website of the Ministry of Awqaf shows the extensive use of Assad's words: http://mow.gov.sy/.

/في-الأداء-الوطني_للاععاة-من_أقو ال_السي/21 mow.gov.sy
} 
submission to religion. It is here that it becomes clear that the religious sector is under the complete domination of the regime.

On the website, Assad's words are strongly endorsed and displayed as formal and official guidance. The quotes from his speeches are carefully chosen to reflect the 'Mohammedan' and 'moderate' approach that Assad has striven to construct in his political discourse. This is an approach constructed with the intention to be contrasted with what Assad called the protesters' 'extreme' interpretation of Islam. ${ }^{42}$ This effective propagation of a modernist approach stresses being reasonable, moderate, and beneficial to the national interest.

In 2014, under the direction of minister al-Sayyed, the ministry developed an encyclopaedia entitled 'Jurisprudence of Crisis'. This was totally guided by President Assad's strategy to 'correct fourteen centuries of false interpretations of Islam'. The rhetoric surrounding the encyclopaedia's creation is that it deploys religious faith as requiring reconstruction and reformulation. In an interview, the minister stressed that the encyclopaedia produced Islamic thinking rooted in the sources of Islamic legislation, claimed 'to save a Muslim who has become the target of intravenous murder and slaughter, until it is said that Islam kills its Muslims' ${ }^{43} \mathrm{He}$ added that the 'Jurisprudence of Crisis' was unprecedented in any Islamic context, positioning Syria ahead of any other Islamic country as it had revitalized the arguments surrounding strife and sedition in the Islamic world. Following Assad's arguments and conceptualization of the conflict, the minister emphasized the many commonalities between the crises that the Islamic world had experienced throughout history, especially the strife of takfir (excommunication). Sayyed further noted that the comprehensive document dealing with the Syrian crisis applied to any conflict affecting any Islamic country as a result of what he called the 'global conspiracy against this nation'. But he said the

\footnotetext{
${ }^{42}$ See Figure ..

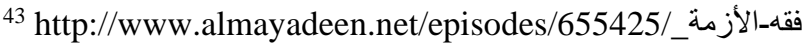


development of the 'Jurisprudence of Crisis' was a positive and necessary development, especially at that juncture.

It is clear that, through the 'Jurisprudence of Crisis', the Ba' athist regime set out to regulate the religious domain through full subordination to and merger with the political domain. From the table of contents onwards, it follows Assad's words closely, and on publication the document was accompanied by public engagement and interactions among the various religious schools in Syria. A look at the videos released as part of this campaign confirms the implementation of Assad's strategy to place religious faith as a method of conflict resolution that would in turn demonize any political activism against the state. In this sense, Assad has become the beacon of wisdom and moderation of Islamic faith.

The slick and premeditated video interviews by various ulama reveal that the political ideology and strategy dictated by President Assad cannot be separated from their own religious views. ${ }^{44}$ This plays a further vital role in propagating an Islamic culture in the public domain that focuses on perpetuating religious rhetoric as an essential component in uniting the nation against terrorism, sectarianism, and discord. This proliferation of officially approved media messages by ulama preaching about being true believers and supporting the state highlights the shift in official discourse. This is evident in a long-standing Ba' athist slogan: 'Religion is to God and Nation (watan) is to all'. It should be noted that, in light of the political turmoil affecting various countries in the region, the 'Jurisprudence of Crisis' has recently been used as a strategy by other Arab countries, such as Saudi Arabia (al-Majed, 2018). ${ }^{45}$

\footnotetext{
${ }^{44}$ In this lecture as part of a series of strategic attempts to counter terrorism and extremism organized and delivered by the Youth Religious Team, Abdullah al-Sayyed (son of the Minister of Awqaf) starts his lecture on 'reforming the religious rhetoric by rationalising it' by stating that the process of rationalizing and logicalizing religious belief emanates from and closely follows Bashar al-Assad's instructions in his extensive meetings with male and female ulama. The full video can be found at https://www.youtube.com/watch?v=4cdRVPs5F5Y\&feature=youtu.be. 45 al-Majed, Hamad. 2018. 'The Jurisprudence of National Crises.' Middle East Newspaper, issue 14595,

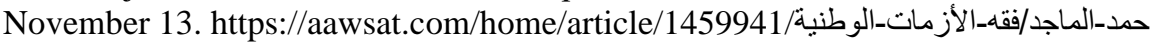


It is important to emphasize that, since the ascendance of the Assads, there has never been any neutralization of the religious institution in Syria. Rather, there has been a process of politicization and depoliticization in which the $\mathrm{Ba}$ 'athist regime has capitalized on ulama to maintain authority and hegemony. The post-2011 era marks its complete monopoly over the religious sector where ulama are no longer able to retain any autonomy resembling what they experienced between 2005 and 2008, which allowed them to criticize, challenge, and seek authority from Assad (Pierret, 2013: 2-4; 197). This unconditional, unquestioning support for and endorsement of the regime's political rhetoric is evidenced in the number of lectures, workshops, and events sponsored by Ba'athist organizations to promote what is termed 'moderate' and 'reformed' Islam. This endorsement of the Ba'athist conception of Islam is clear in the new partnership of clearly Ba'athist-affiliated organisations such as the

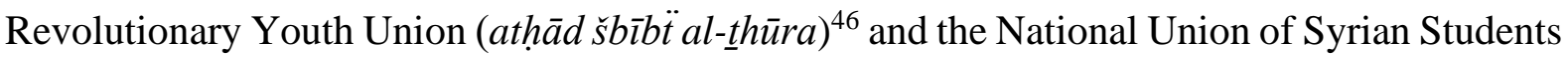
(al- 'Itihad al-watani li-talabet Suria) with the Ministry of Awqaf. These two organizations are known for their surveillance activities, acting partly as agents for the Mukhabarat intelligence service. ${ }^{47}$ There is no doubt the Ba'athist state has always practised micro-surveillance over the religious discourse, with a security agent ('unsur mukhabarat) reading the Friday khutba before its delivery in the mosque to make sure that it contains nothing against the state. However, this was more about surveillance than imposing a standardized interpretation of the Quran (see Pierret, 2011: 76).

A series of weekly lectures delivered by the minister within the project 'The Inclusive and Modern Interpretation' (al-tafsir al'asri aljami') closely followed and endorsed Assad's foundational and intellectual pillars of how the religious discourse should be adapted. In one lecture that attracted ridicule among the opposition, titled 'Interpreting the Quran in light of

\footnotetext{
${ }^{46}$ See Figures 1 and 3.

${ }^{47}$ Members would monitor the behaviour and activities of any university or high school student, flagging up any suspicious activity that might constitute a threat to the security of the state. See figures 1 and 3
} 
Assad's intellectual foundations of reforming religion', ${ }^{48}$ the utilization of Assad's conceptions of Islam goes beyond mere strategic co-optation to full endorsement and conflation with a state that previously championed secularism as its official identity.

In a lecture by Dr al-Sayyed titled 'The Regulations and Rules in Interpreting the Quran' on 31 July 2018, he states that this 'new interpretation is based on Assad's intellectual foundations on religious reform' (murtakazaat al-Assad). In a short video summarizing the lecture, it is clear that this new interpretation is a matter not of reforming or propagating a moderate or modern understanding of Islam but, rather, strictly applying to the Quran Assad's foundations and definitions of what Islam is. Al-Sayyed reaffirms Assad's statement about holding the 'Mohammedan banner' (rayet Mohammad). ${ }^{49}$

An interview on 'Panorama' in 2017 about the ministry's role in conflict resolution reiterates that its approach employs and depends on Assad's foundations on how to update the religious discourse ${ }^{50} \mathrm{Al}$-Sayyed states that the religious institution has been activated in terms of reforming the religious discourse through initiating large projects in which the ministry was able to fight the terrorist war in Syria. These projects include improving the religious curriculum, the idea of the Youth Religious Group (YRG), the 'Jurisprudence of Crisis' and the morality project (mashr'u fadila), and reforming the religious discourse.

In another context, where the audience for Assad's words is the West, he insists on the role of religion as part of his political strategy on conflict resolution. In an interview in November 2019 with Monica Maggioni for Italy's RAI News $24,{ }^{51}$ he insisted on the role of religious

\footnotetext{
48 https://orient-news.net/ar/news_show/152134/0/أوزار

${ }^{49}$ https://www.youtube.com/watch?v=IUDlvGjlKwk\&feature=youtu.be.

50 See Figure 2.

${ }^{51}$ RAI News 24 refused to air the interview with Assad, but it was broadcast on December 9, 2019 on various Syrian national media outlets and posted on the presidency's Facebook page. The wording used in this interview concerning the role of religion in conflict resolution was strongly featured on the Ministry of Awqaf's Facebook page (markaz Irshad al-ta'heel).
} 
leaders in reconstructing what belief means in the minds of those living outside the control of the Ba' athist government. More importantly, for him reconciliation was through reconstructing what religion is: 'The first part of the solution is religious, because this ideology is a religious ideology, and the Syrian religious clerics, or let's say the religious institution in Syria, is making a very strong effort in that regard, and they succeeded; they succeeded at helping those people understanding the real religion'.

This reconstruction or reforming of religious belief was marked by the creation of the YRT, which consists of young ulama (both male and female wearing modern dress) to conduct lectures and communications with media that have wider access to Syrian youth than the former approach or senior ulama. While one cannot fail to note that the Ba'athist approach to contain and monopolize religion was previously achieved by the creation of Institutes for the Memorization of the Quran (Ma'ahid Hafi z al-Asad li-Tahfi z al-Qur'an) in the 1980s by Hafez al-Assad, this was, as Pierret argues, no more than 'to symbolically underline the President's reverence for the Holy Book' $(2013: 72)^{52}$ and the establishment of private higher Islamic institutes ${ }^{53}$ was only initiated by the state as 'responding to a genuine social demand' (Pierret, 2013: 73). It is beyond the scope of this article to assess the extent of the YRT's popularity on the ground or whether it is perceived as an extension of some $\mathrm{Ba}$ 'athist rhetoric that has always attracted concern and ridicule by the people. However, these various activities - ranging from lectures, workshops and conferences to close explicit collaboration and partnership with $\mathrm{Ba}$ 'athist institutions - indicate a shift in the relationship between the state and religion from co-optation to conflation. ${ }^{54}$

\footnotetext{
${ }^{52}$ Pierret, 2013.

${ }^{53}$ For more details, see Pierret, 2013: 72-73.

/الفريق-الديني-الثبابي/54 For YRT videos and activities, see http://mow.gov.sy/category
} 
In this respect, the shift seen in the regime's approach is that, for the first time in Syria, an official Ba'athist institution such as the National Union of Syrian Students now sponsors religious workshops and holds roundtable discussions on how to modernize and rejuvenate the religious discourse as a prerequisite to reforming those who were under the influence of the takfiri discourse or living outside government rule. Moreover, lectures in tafsir (exegesis) of the Quran are beginning, with ulama carrying out this theological practice based on Assad's intellectual foundations. It appears that these events are the first of their kind in terms of officially breaking down the boundaries between Islam and $\mathrm{Ba}$ athism. This goes beyond collaboration or co-optation; it is direct control over and colonization of the religious discourse. It marks the end of any autonomy or authority of the religious institution in Syria.

We can conclude that over the past 50 years the $\mathrm{Ba}$ 'athist regime has experimented with a number of approaches to define the state-religion relationship. State policy has alternated through confrontation, co-optation and relative relaxation to intense monopolization of the religious discourse. This adapted modelling of the relationship between the regime and the religious institution restricts any bargain or deal initiated by the religious sector. Instead, religion becomes a vital determinant that is utilized, monopolized, and completely hegemonized by the regime, not by harmonizing Islam but by Ba'athifying it.

\section{Conclusion}

Implicit in this article's focus on how the state-religion relationship has become Ba'athified since 2011 is an understanding of how legitimacy has been constructed in the official narrative of the state. Given that legitimacy is an imprecise, multifaceted concept and the difficulty of evaluating people's consent to the regime, this article has attempted to contribute to the general understanding of the impact of ideational tools used by strong authoritarian regimes to 
legitimize its polity. More particularly, the goal of this research is to contribute to a better understanding of the shift in the use of religious rhetoric by Bashar al-Assad after the 2011 uprising.

The deviation from secularism in the official political discourse since 2011 has been primarily driven by two factors: the weakness of state legitimacy and authority, and the shift from the paradigms of co-optation and rapprochement to one based on conflation and synonymization of religious faith and patriotic sentiment. In this context, the newly deployed religious rhetoric in the presidential political discourse represented a change of paradigm in the relationship between the state and religious authority. This article has therefore focused on understanding the regime's ability to construct a clientelist network that provided it with an official legitimatization through the co-optation of well-known Sunni ulama. It is important to note that religious rhetoric propagated by these ulama might have had a counter-influence on people's perception of religion, and more research is needed on the impact of the failure of these ulama to be the voice of society's most vulnerable.

While nation and state are not synonymous, under Syria's Ba'athist regime they have been conflated: supporting the Ba'ath Party and belonging to the nation are understood to be the same. Hence, while Bashar al-Assad relied on the pre-existing co-opted relationship with religious elites to consolidate his rule after he took office, since 2011 we see the containment of domestically adapted religious $\mathrm{Ba}$ athist narratives that promote the role of religion in establishing national unity and battling discord and extremism, which in turn highlights the new networks of patronage between the state and the Syrian Sunni community.

Two things can be discerned in the post-2011 uprising. First, the state's promotion of religious discourse is not limited to legitimacy but is also used as a tool of the state's resilience against the protesters and a card to ensure its survival. Second, this not a 'newly adopted' 
religious rhetoric per se or a reformulation of religious-secular relations, but a Ba'athification of an officially constructed version of Islam that is heavily conditioned by and subscribed to the official narrative's definition of what a true Muslim and a true patriot are. Thus, before 2011 the political use of religion took the form of control and compliance rather than conflation. This study has investigated how Assad's rhetoric has, by the Ba'athification of Islam, essentialized national belonging and identity as juxtaposed with religious belief in which supporting the $\mathrm{Ba}$ 'athist regime becomes synonymous with what Assad termed a true religious faith. In this Ba'athified version, meticulously adapted and constructed by Assad, political dissidence becomes synonymous with religious non-belief.

However, as emphasized by Khatib, the Syrian state's promotion of religion is not concomitant with the uprising in 2011; rather, this official revitalization of religious discourse was maintained as part of upgrading authoritarianism ${ }^{55}$ and further consolidates the state's authority. Consequently, there is no hesitation in stating that the promotion of religious discourse by the Ba'athist regime was followed by a strategy to garner legitimacy and consolidate authority. Hence, this paper takes as a starting point the notion that the regime was aware that secularism was not a bottom-up process but, rather, imposed from above. In other words, secularism as a framing ideology for the diverse Syrian communities did not penetrate Syrian society, nor was it accepted by the Sunni majority. The Ba'athist regime therefore allowed a sub-state identity to emerge. However, this identity was meticulously observed and conditioned to conform to the Ba'athist definition of belonging and identity. This adherence and subscription to the Ba'athist national model by the Sunni majority took place through a process of co-optation and partnership.

\footnotetext{
${ }^{55}$ Heydemann, S. 2013. 'Syria and the Future of Authoritarianism'. Journal of Democracy 24(4), 59-73.
} 
We can conclude that the relationship between state and religion has been highly complex and contradictory since Hafez al-Assad came to power in 1970 because the ulama in Syria did not have a unified reaction to the rise of the Ba'ath Party in 1963. Consequently, while the state-religion relationship was one of competition and occasional confrontation, after 2011 the Ba'athist regime adopted an intensified religious rhetoric in an attempt to push religious institutions to the fore by holding them responsible for the conflict. This raises the question of how the Syrian conflict has been defined in the official rhetoric.

While this article has focused on the reconfiguration of relations between the state and religion since 2011 and how Assad's strategy to deploy religious faith as a tool to legitimize and retain his authority has been implemented, it is still early to speculate whether the Ba' athist regime will continue to rely on non-state actors as crucial to its existence and social acceptability. However, the current Syrian crisis has certainly allowed the autocratic Ba' athist state to construct religious faith and ulama as allies of political tyranny and a cause of conflict, but also as a possible constraint on political despotism, a source of social cohesion and stability, and a potential ally in promoting social justice.

My future research should investigate whether this appropriation by the Ba' athist regime of state-religion boundaries since 2011 constitutes another challenge to establishing peace, reconciliation and resolution as making religion a determining pillar in ensuring the regime's survival will also remove its relative leverage for promoting reconciliation. This stems from the reaction of millions of displaced Syrians, who perceive this new partnership as a hindrance to building trust between those who have not only condoned, normalized, and justified atrocities by the Syrian army but also acted as an official representative of the Ba' athist state. ${ }^{56}$

\footnotetext{
${ }^{56}$ The negative role of the religious institution that would hinder any future positive role in establishing peace lies in the complicity of ulama in not only greeting or gratifying the role of the army but also even expressing condolences on the death of General Issam Zahreddin, who played a major role in leading the Syrian regime's forces on several fronts. He is known for his crimes against humanity.
} 



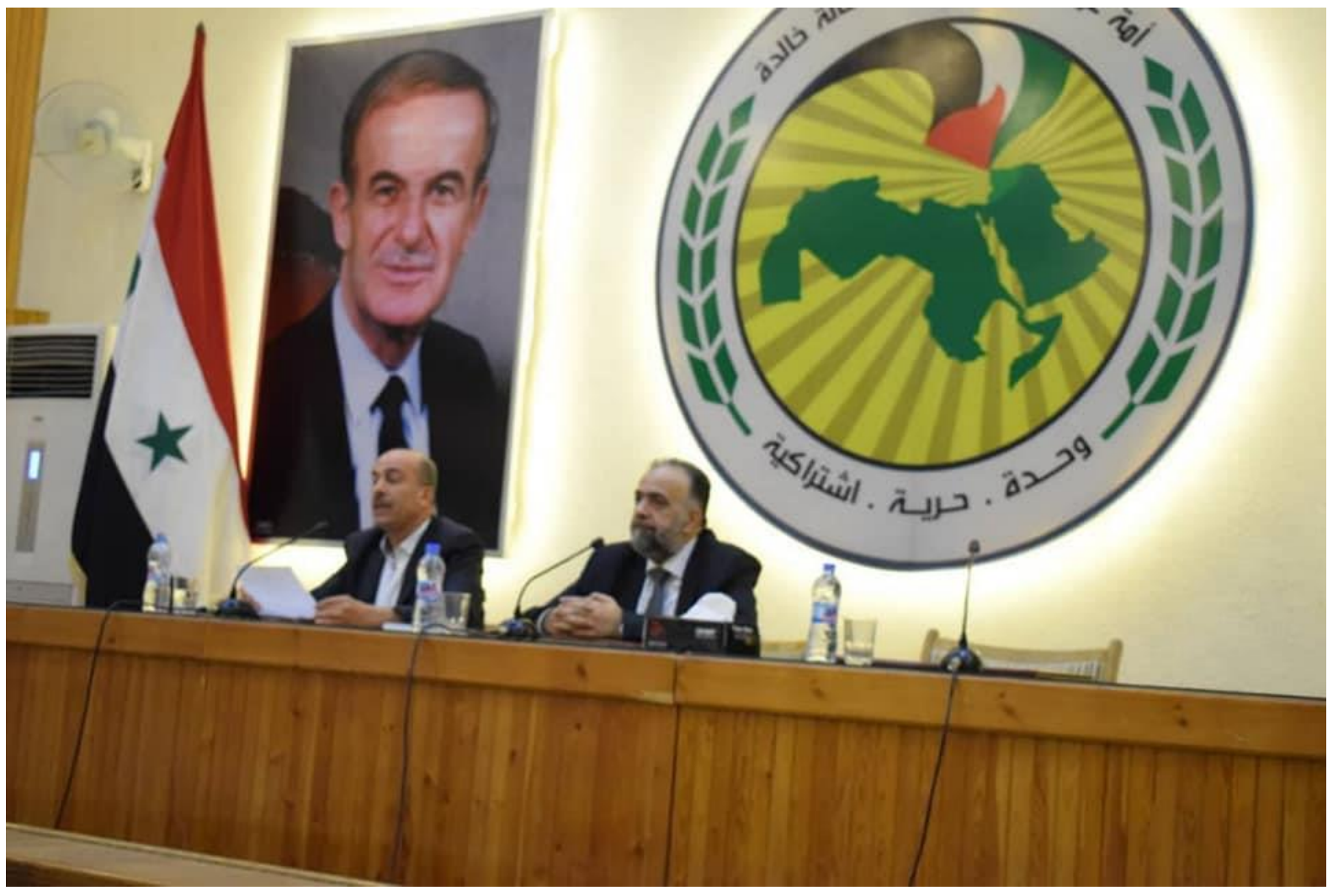

Figure 1. A lecture on March 2, 2019 by the Minister of Awqaf, Dr Mohammad Abdul Sattar al-Sayyed, sponsored by the $B a$ 'ath Party. The lecture is about the need to reform religious discourse in light of Bashar-al Assad's intellectual pillars of Islam. (Ministry of Awqaf Facebook page) 


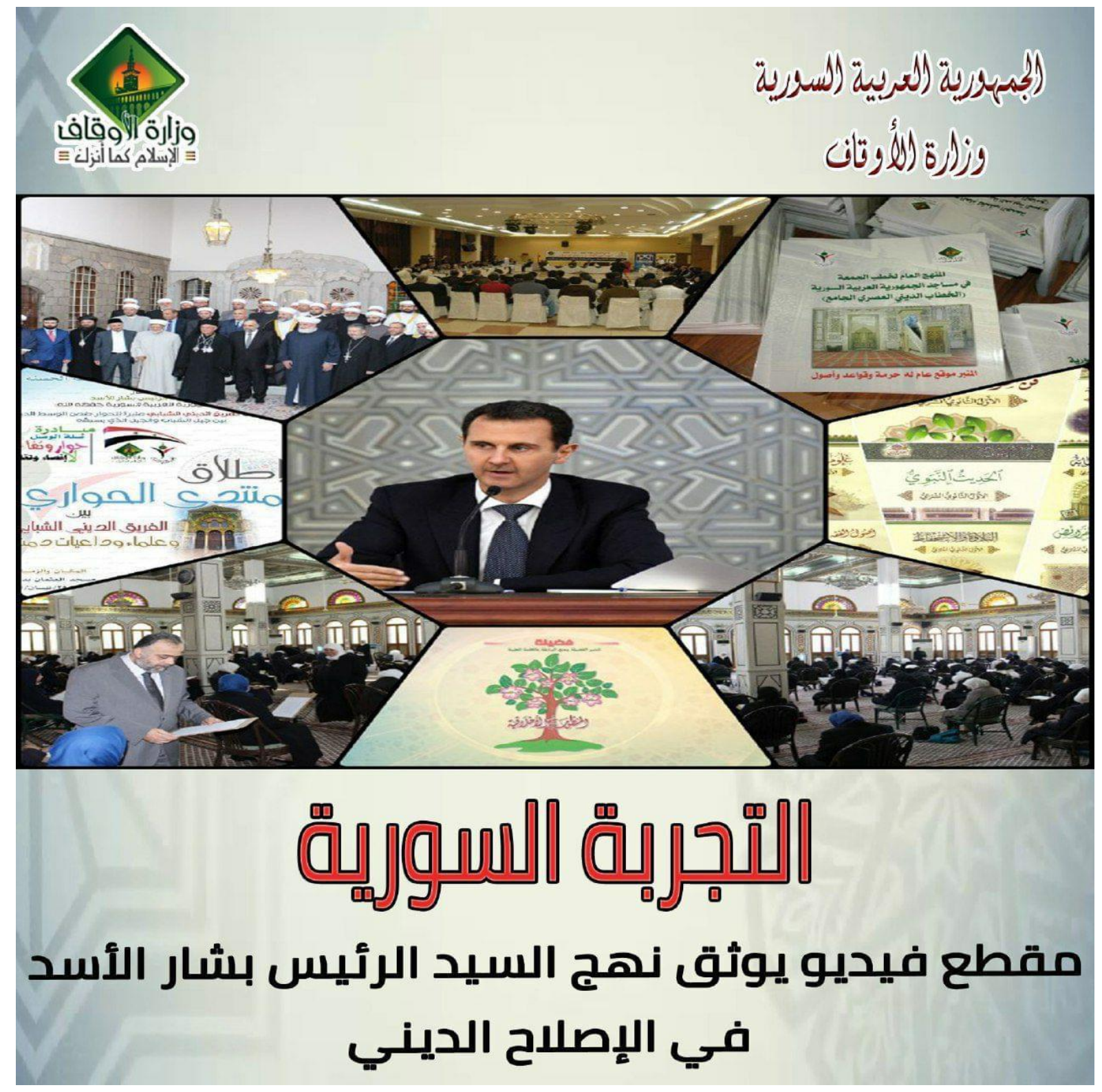

Figure 2. 'The Syrian Experience': video documenting President Bashar al-Assad's strategy on religious reformation. November 30, 2017.

https://www.facebook.com/awkafsyrian/photos/a.969426816418017/1920844121276277/?type=3\&theater 


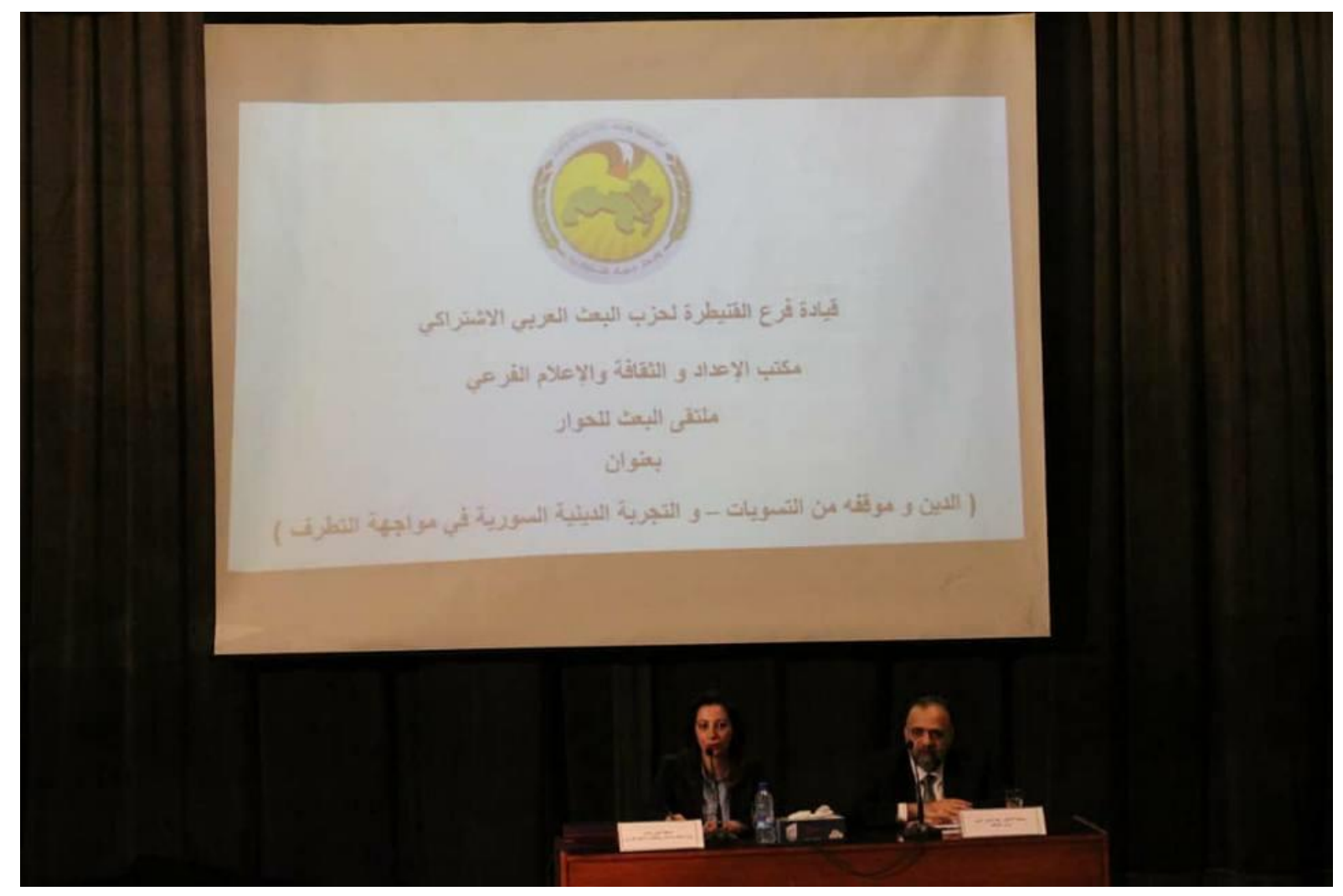

Figure 3. Dialogue between Ba' ath Arab Socialist Party and the Ministry of Awqaf on the role of religion in reconciliation and the Syrian experience in fighting extremism, May 13, 2018.

https://www.facebook.com/awkafsyrian/photos/a.969426816418017/2117022768325077/?type=3 

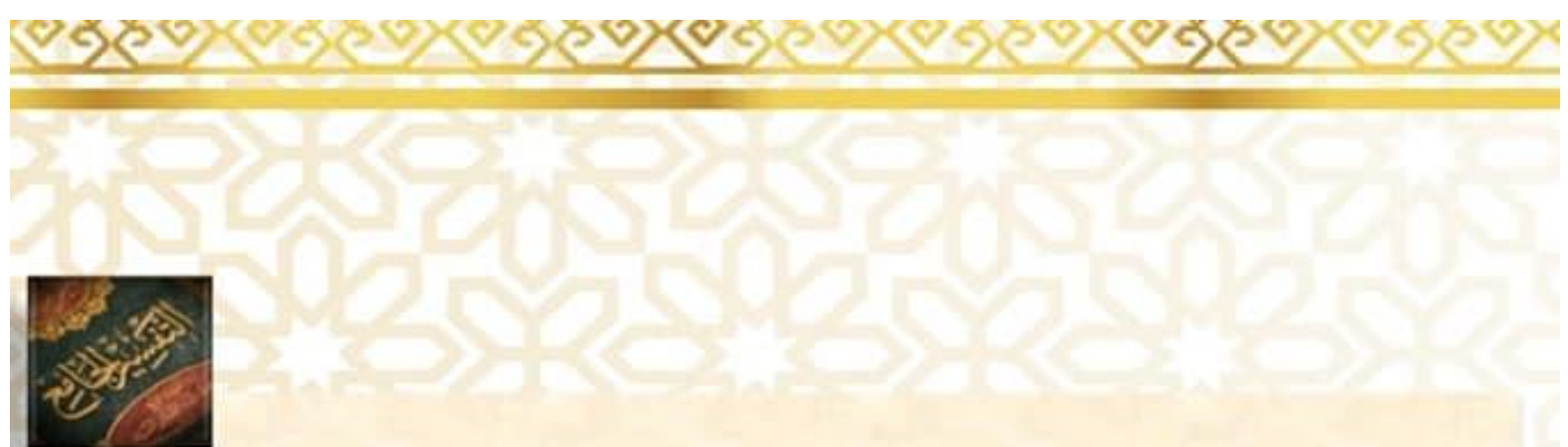

Quoted from The Comprehensive Interpretation "AL-TAFSIR AL-JAMI"

Islam has corrected concepts and terminology .through practices and goals

The term mosque is not enough without the real .purposes of the Prostrate

Allah the Almighty describes a mosque of being (خِركاً)

(causing harm) and says:

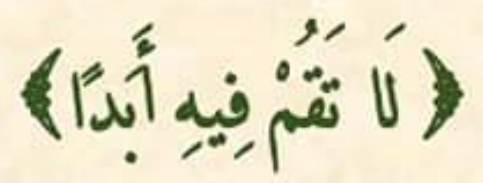

(Do not stand [for prayer] within it - ever) 
Quoted from The Comprehensive Interpretation "AL-TAFSIR AL-JAMI"

Allah the Almighty says:

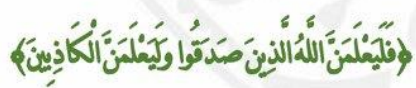

and Allah will surely make evident those who are truthful, and He will surely make evident the liars

Lying and falsifying facts cause a moral destruction greater than that is caused by calamities.

When the morning and the evening would come upon people while they are lying, falsifying, fabricating and calumniating, there would be no values, virtues or morals in societies.

Allah the Almighty says:

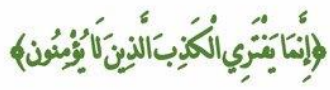

They only invent falsehood who do not believe

\section{And the Prophet [PBUH] said thrice}

"Should I inform you out the greatest of the great sins?"

They said, "Yes, O Allah's Messenger (PBUH)!" He said

"To join others as partners with Allah and to be undutiful to one's parents."

The Prophet (PBUH) then sat up after he had been reclining (on a pillow) and said:

"And I warn you against making a false statement and giving a false testimony", and he kept on saying that warning till we thought he would not stop. [Sahih al-Bukhari]

Furthermore, when groups of people turn into beehives in a factory of lies, that has a wide area and roaring machines, and they help each other in fabricating lies, forging facts, then recording them, escalating them, moving them, cutting and pasting them, consequently, the truth fades out and falsehood increases .And the Prophet [PBUH] said:

"There will come to the people years of treachery, when the liar will be regarded as honest, and the honest man will be regarded as a liar; the traitor will be regarded as faithful, and the faithful man will be regarded as a traitor; and the Ruwaibidah will decide matters"

It was said: 'Who are the Ruwaibidah?' He said :

"Vile man who controls the affairs of the people"

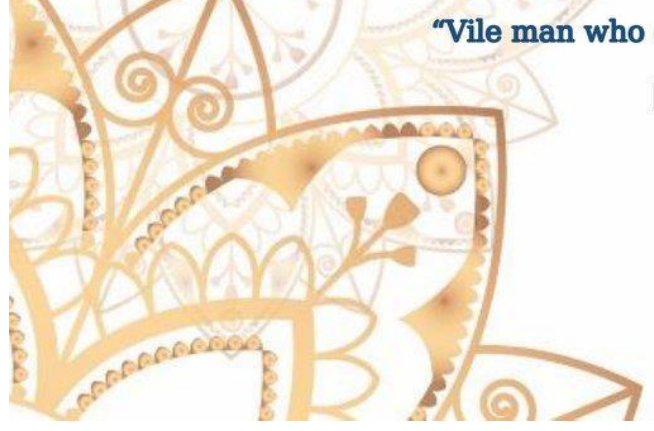

[Sunan Ibn Majah]

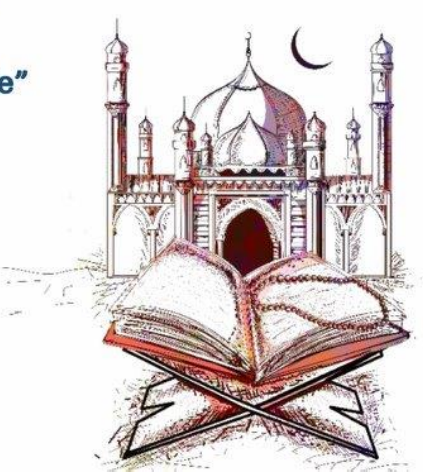

Figure 5. Verses from the Quran and Hadith appealing against any dissemination of misinformation. This can be seen as the ulama's response to Assad's words.( Ministry of Awqaf Facebook account, July 25, 2019.) 